\title{
UPAYA GURU KELAS DALAM MENINGKATKAN DISIPLIN PADA ANAK USIA 4-5 TAHUN MELALUI METODE PEMBIASAAN
}

\author{
Noor Ishma ${ }^{1}$, Lilis Purwani ${ }^{2}$ \\ STAI Darunnajah Jakarta ${ }^{1}$, STAI Darunnajah Jakarta ${ }^{2}$ \\ Email : noor.ishma@gmail.com ${ }^{1}$, lilispurwani@gmail.com ${ }^{2}$
}

\begin{abstract}
This research started from the background of the lack of understanding of the class teacher regarding instilling discipline in children from an early age, namely awareness in discipline including, arriving on time, obeying class rules, tidying up toys after use, queuing and being orderly. The formulation of the problem in this paper is how the class teacher's efforts in improving the discipline of children aged 4-5 years through the method of habituation. The purpose of this study is to describe the discipline of children aged 4-5 years through the method of habituation. This writing is Classroom Action Research, which is carried out through 3 cycles with each cycle of stages being planning, implementing, observing and reflecting. This writing took place in Darunnajah Islamic Kindergarten 1. The data was collected by observation, interviews and documentation. The results of the writing show: 1) The results showed an increase in discipline with the habituation method in the first cycle which was in the category of developing according to expectations amounting to $56.4 \%$, then in the second cycle it became $83.3 \%$ and in the third cycle it reached 93.6\%. 2) Children's discipline can be improved by the habituation method by providing examples to students, providing motivation, in instilling discipline carried out continuously and consistently. Besides that, it is also accompanied by clapping and songs, reading Islamic stories, accompanied by giving rewards in the form of praise and star stickers.
\end{abstract}

Keywords : discipline, children aged 4-5 years, habituation 
Abstrak : Penelitian ini berawal dari latar belakang dari kurangnya kepahaman Guru kelas mengenai penanaman disiplin anak sejak usia dini yaitu kesadaran dalam disiplin meliputi, datang tepat waktu, kepatuhan pada peraturan kelas, merapihkan mainan setelah dipakai, mengantri dan tertib. Rumusan masalah pada penulisan ini adalah bagaimana upaya guru kelas dalam meningkatkan disiplin anak usia 4-5 tahun melalui metode pembiasaan. Tujuan penelitian ini yaitu untuk mendeskripsikan disiplin anak usia 4-5 tahun melalui metode pembiasaan. Penulisan ini merupakan Penelitian Tindakan Kelas (classroom action research), yang dilakukan melalui 3 siklus dengan setiap siklus tahapannya adalah perencanaan, pelaksanaan, observasi dan refleksi. Penulisan ini mengambil tempat di TK Islam Darunnajah 1. Pengumpulan data dilakukan dengan observasi, wawancara dan dokumentasi. Hasil penulisan menunjukkan : 1) Hasil penelitian memperlihatkan adanya peningkatan disiplin dengan metode pembiasaan pada siklus I yang berada dalam kategori berkembang sesuai harapan berjumlah $56,4 \%$, lalu pada siklus II menjadi 83,3 \% dan pada siklus III mencapai 93,6 \%. 2) Disiplin anak dapat ditingkatkan dengan metode pembiasaan dengan memberikan contoh teladan kepada peserta didik, memberikan motivasi, dalam menanamkan kedisiplinan dilakukan secara kontinyu dan konsisten. Selain itu juga diiringi dengan tepuk dan lagu, membacakan cerita-cerita Islami, disertai dengan pemberian reward berupa pujian dan stiker bintang.

Kata Kunci : disiplin, anak usia 4-5 tahun, pembiasaan. 


\section{PENDAHULUAN}

Pendidikan di TK berupaya untuk mengembangkan potensi yang dimiliki oleh peserta didik. Pendidikan sebagaimana tercantum dalam Undang-undang Republik Indonesia nomor 20 tahun 2003 tentang sistem pendidikan nasional, pada Bab I pasal 1 ayat 1 yang berbunyi:

"Pendidikan merupakan usaha sadar dan terencana untuk mewujudkan suasana belajar dan proses pembelajaran agar peserta didik secara aktif mengembangkan potensi dirinya untuk memiliki kekuatan spiritual keagamaan, pengendalian diri, kepribadian, kecerdasan, akhlak mulia, serta keterampilan yang diperlukan dirinya, masyarakat, bangsa, dan negara."

Disiplin adalah adanya kesediaan untuk mematuhi ketentuan atau peraturan yang berlaku. Kepatuhan bukan karena paksaan, tetapi kepatuhan atas dasar kesadaran tentang nilai dan pentingnya mematuhi peraturan-peraturan itu. Maka dari itu peran guru kelas dalam menanamkan disiplin peserta didik sekolah merupakan hal yang sangat penting khususnya pendidikan di Taman Kanakkanak. Pendidikan di TK bertujuan melatih anak untuk dapat mengontrol diri, bertanggung jawab, dan nilai-nilai yang berlaku dimasyarakat, sehingga diharapkan peserta didik dapat menjalani kehidupan bermasyarakat dengan baik serta menjadi warga negara yang taat dan patuh.

Disiplin dapat membentuk kejiwaan pada anak untuk memahami peraturan sehinggga ia pun mengerti kapan saat yang tepat untuk melaksanakan peraturan, dan kapan pula harus mengesampingkan. Peraturan itu sendiri ada dalam keseharian hidup anak. Kondisi kejiwaannya memang masih butuh diatur sehingga seorang anak akan merasa tentram bila hidup teratur. Sebagai contoh adalah peraturan tentang makan, shalat, puasa, masuk sekolah, sampai waktu bermainnya.

Berbagai peraturan atau tata tertib disekolah dibuat dan diberlakukan untuk melatih anak menjadi pribadi yang disiplin, seperti disiplin di sekolah meliputi menggunakan seragam sekolah sesuai dengan jadwal, datang ke sekolah tepat waktu, berbaris pada waktu masuk kelas, meletakan sepatu dan tas di tempat masing-masing, dapat duduk dengan tenang, mengembalikan mainan setelah dipakai, mengikuti proses belajar mengajar dari awal sampai pada waktu pulang sekolah. Semua kegiatan pembelajaran di TK menanamkan nilai disiplin baik pembelajaran yang terstruktur ( kurikulum ) maupun yang tidak terstruktur.

Masalah mengenai disiplin pada anak pra sekolah sering menjadi permasalahan bagi lembaga pendidikan anak usia dini. Berdasarkan hasil observasi pada tanggal 23 November 2015 di salah satu sekolah di Jakarta Selatan yaitu, rendahnya disiplin pada anak seperti datang terlambat, jadwal baju seragam tidak sesuai, tidak mau merapihkan kembali mainan setelah dipakai, bertengkar di kelas, tidak mau mengerjakan dan menyelesaikan tugas, ditemani orang tua atau pengasuh di dalam kelas, mengabaikan perintah guru, tidak mau mengantri pada saat cuci tangan atau wudhu. Dengan persentase anak yang menunjukkan kedisiplinan berkembang sesuai harapan $28,2 \%$, anak yang kedisiplinannya mulai muncul 51,3\%, dan anak yang kedisiplinannya belum muncul sebesar 20,5\%. Selama ini Pendidik telah melakukan penegakan disiplin dengan berbagai macam metode, namun dalam proses belajar mengajar belum konsisten dalam penerapannya, sehingga belum dapat meningkatkan disiplin anak secara optimal.

Guru mempunyai peran sebagai controller, organizer, assesor, prompter, participant, resource, tutor dan observer. Maka dari itu, guru merupakan salah 
satu orang yang berpengaruh dalam melatih kedisiplinan peserta didik. Karena guru yang baik merupakan idola bagi peserta didik dan akan ditiru perilaku dan perkataannya. Sehingga upaya guru dalam meningkatkan disiplin pada anak usia 4-5 tahun melalui metode pembiasaan sangat diperlukan.

Berdasarkan latar belakang permasalahan diatas, mengingat pentingnya disiplin pada anak usia dini, maka fokus penelitian ini adalah Upaya Guru Kelas Dalam Meningkatkan Disiplin pada Anak Usia 4-5 Tahun Melalui Metode Pembiasaan. Perumusan masalah pada penelitian ini yaitu bagaimana upaya guru kelas dalam meningkatkan disiplin anak usia 4-5 tahun melalui metode pembiasaan. Tujuan penelitian ini yaitu untuk mendeskripsikan disiplin anak usia 4-5 tahun melalui metode pembiasaan.

Manfaat penelitian ini adalah secara teoritik, penelitian ini diharapkan dapat dijadikan sarana pembelajaran dan menambah wawasan tentang disiplin di sekolah pada anak untuk memahami ilmu pendidikan anak usia dini, khususnya upaya guru kelas dalam meningkatkan disiplin anak usia 4-5 tahun melalui metode pembiasaan. Sedangkan secara praktis, bagi lembaga, hasil dari penelitian ini diharapakan dapat menjadi informasi dan bahan pertimbangan dalam menerapkan disiplin murid yang sesuai dengan tahap perkembangannya dan meningkatkan prestasi bagi sekolah. Bagi guru kelas, hasil dari penelitian ini diarapkan dapat berguna bagi mengembangkan proses belajar mengajar di sekolah yang dapat melatih dan meningkatkan kedisiplinan murid. Dan bagi anak, yaitu agar anak dapat memiliki kedisiplinan diri sehingga dapat melakukan aktivitas pembelajaran berjalan lancar serta mencapai hasil belajar yang baik.

\section{METODE PENELITIAN}

Penelitian ini menggunakan metode Penelitian Tindakan Kelas (classroom action research). Penelitian tindakan kelas adalah aktivitas mencermati suatu objek tertentu melalui metodologi ilmiah dengan mengumpulkan data-data dan dianalisis untuk menyelesaikan suatu masalah dengan tujuan tertentu yang berbentuk siklus kegiatan dengan tujuan untuk memperbaiki atau meningkatkan suatu masalah dalam proses belajar mengajar yang dilakukan pada sekelompok siswa dalam waktu dan pelajaran yang sama dari seorang guru.

Tahap-tahap penelitian dalam masing-masing tindakan terjadi secara berulang yang akhirnya menghasilkan beberapa tindakan dalam penelitian tindakan kelas. Tahap-tahap tersebut berbentuk spiral (1985). Berikut ini adalah gambar/ skema model spiral penelitian tindakan menurut Hopkins:

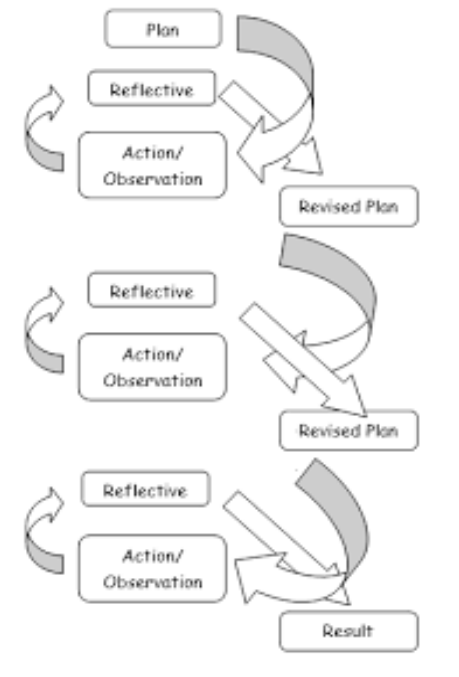

Gambar 3.1 Model spiral penelitian tindakan Hopkins 
Setting lokasi bertempat di TK Islam Darunnajah 1 Jalan Ulujami Raya no. 86 Pesanggrahan, Jakarta Selatan. Dengan subjek penelitian ditujukan kepada anak kelas A yaitu usia 4-5 tahun yang berjumlah 13 anak.

Waktu penelitian ini direncanakan akan dilaksanakan mulai pada bulan November sampai Desember 2015 pada semester I, tahun ajaran 2015-2016.

Prosedur penelitian ini dilakukan dengan : perencanaan (planning), pelaksanaan (acting), pengamatan (observating) dan reflaksi (reflecting). Tiap siklus terdiri dari 4 tahapan dan langkah pengajaran tersebut.

teknik pengumpulan data penelitian ini menggunakan tiga teknik yaitu observasi, wawancara dan dokumentasi.

Tabel 3.1

Kisi-kisi Instrumen Disiplin Anak 4-5 Tahun

\begin{tabular}{|c|c|c|c|c|}
\hline Variabel & Indikator & Aspek Penilaian & Item & Jumlah \\
\hline \multirow{6}{*}{$\begin{array}{l}\text { Disiplin anak } \\
\text { usia } 4-5 \\
\text { tahun }\end{array}$} & \multirow{2}{*}{$\begin{array}{c}\text { Patuh terhadap } \\
\text { aturan }\end{array}$} & $\begin{array}{c}\text { Anak mampu } \\
\text { mengenal peraturan }\end{array}$ & 1 & \multirow{2}{*}{2} \\
\hline & & $\begin{array}{c}\text { Anak mampu disiplin } \\
\text { dalam waktu }\end{array}$ & 2 & \\
\hline & \multirow{2}{*}{$\begin{array}{l}\text { Mengin-dahkan } \\
\text { petunjuk-petunjuk } \\
\text { yang berlaku }\end{array}$} & $\begin{array}{l}\text { Anak mampu taat } \\
\text { terhadap peraturan }\end{array}$ & 3 & \multirow{2}{*}{2} \\
\hline & & $\begin{array}{l}\text { Anak mampu patuh } \\
\text { terhadap perintah }\end{array}$ & 4 & \\
\hline & \multirow{2}{*}{$\begin{array}{l}\text { Tidak membang- } \\
\text { kang pada } \\
\text { peraturan yang } \\
\text { berlaku }\end{array}$} & $\begin{array}{c}\text { Anak mampu } \\
\text { bertanggung jawab } \\
\text { terhadap diri sendiri }\end{array}$ & 5 & \multirow{2}{*}{2} \\
\hline & & $\begin{array}{c}\text { Anak mampu } \\
\text { menyelesai-kan tugas } \\
\text { pada waktunya }\end{array}$ & 6 & \\
\hline
\end{tabular}

Teknik analisis data pada penelitian ini, menggunakan analisis deskripsi kualitatif, yaitu suatu metode penelitian yang bersifat menggambarkan kenyataan atau fakta sesuai dengan data yang diperoleh dengan tujuan untuk mengetahui hasil belajar yang dicapai siswa juga untuk mengetahui respon siswa terhadap kegiatan serta aktivitas siswa selama proses belajar mengajar berlangsung. Dengan target pencapaian 90\% disiplin anak usia 4-5 tahun meningkat melalui metode pembiasaan.

\section{TINJAUAN TEORI}

\section{Anak Usia 4-5 Tahun}

Piaget menyatakan bahwa bertahun-tahun awal perkembangan manusia merupakan saat yang tepat untuk mengenalkan berbagai konsep sederhana sebagai landasan untuk mengembangkan cara berpikir yang lebih kompleks pada tahap-tahap berikutnya.

Anak usia 4-5 tahun di Taman Kanak-kanak berada di kelas A. Adapun tingkat pencapaian perkembangan pada lingkup perkembangan sosial-emosional yaitu: 
Tabel 2.1

Perkembangan Sosial Emosional

\begin{tabular}{|l|l|}
\hline Usia $4-<5$ & Usia $5-\leq 6$ tahun \\
\hline $\begin{array}{l}\text { a. Mentaati aturan yang } \\
\text { berlaku dalam suatu } \\
\text { permainan }\end{array}$ & $\begin{array}{l}\text { a. Mengenal tata karma dan } \\
\text { sopan santun yang sesuai } \\
\text { dengan nilai sosial budaya } \\
\text { setempat }\end{array}$ \\
\hline $\begin{array}{l}\text { b. Menjaga diri sendiri } \\
\text { dari lingkungannya }\end{array}$ & $\begin{array}{l}\text { b. Memahami peraturan dan } \\
\text { disiplin }\end{array}$ \\
\hline
\end{tabular}

2. Disiplin

Menurut Hoffman dalam Moral Development, disiplin berasal dari kata yang sama dengan "disciple", yakni seorang yang belajar atau secara suka rela mengikuti seorang pemimpin. Orang tua dan guru merupakan pemimpin dan anak merupakan murid yang belajar dari mereka cara hidup yang menuju ke hidup yang berguna dan bahagia. Jadi disiplin merupakan cara masyarakat mengajar anak perilaku moral yang disetujui kelompok.

Dalam arti luas disiplin mencakup setiap macam pengaruh yang ditunjukan untuk membantu peserta didik agar dia dapat memahami dan menyesuaikan diri dengan lingkunganya dan juga penting tentang cara menyelesaikan tuntutan yang mungkin ingin ditujukan oleh peserta didik terhadap lingkungannya.

Adapun bentuk pendisiplinan pada anak usia dini yaitu:

a. Disiplin pergi sekolah

b. Disiplin di Sekolah

c. Disiplin merapikan mainan

d. Disiplin memakai pakaian dan sepatu

e. Disiplin bangun tidur

f. Disiplin waktu makan bersama

Amir Daien Indrakusuma dalam Alisuf Sabri mengemukakan bahwa langkah-langkah menenamkan disiplin diri bagi anak antara lain:
a. Pembiasaan
b. Contoh atau teladan
c. Penyadaran
d. Pengawasan

3. Metode Pembiasaan

Definisi metode dalam Kamus Besar Bahasa Indonesia cara kerja yang bersistem untuk memudahkan pelaksanaan suatu kegiatan guna mencapai tujuan yang ditentukan. Sedangkan definisi Pembiasaan (habituation) merupakan proses pembentukan sikap dan perilaku yang relatif menetap dan bersifat otomatis melalui proses pembelajaran yang berulang-ulang.

Berdasarkan dari dua definisi yang telah dijabarkan, maka dapat disimpulkan definisi metode pembiasaan yaitu cara kerja yang bersistem untuk memudahkan pelaksanaan suatu kegiatan atau proses dalam pembentukan sikap, perilaku yang menetap dan melalui proses pembelajaran yang berulang-ulang. 


\section{Guru Kelas}

Dalam Undang-Undang No. 14 tahun 2005 tentang guru dan dosen yang terdapat dalam Bab 1 pasal 1 bahwa: "Guru adalah pendidik profesional dengan tugas utama mendidik, mengajar, membimbing, mengarahkan, melatih, memberikan, menilai, mengevaluasi peserta didik pada pendidikan anak usia dini jalur pendidikan formal, pendidikan dasar, dan pendidikan menengah."

Guru adalah seorang administrator (penggerak), informatory (memberi informasi), konduktor (penghantar), dan sebagainya, dan berkelakuan menurut masyarakat. Dari guru, sebagai pendidik dan pembangun generasi baru diharapkan tingkah laku yang bermoral tinggi demi masa depan bangsa dan Negara.

\section{HASIL DAN PEMBAHASAN}

\section{Hasil penelitian}

1. Hasil Pra Siklus

Data yang diperoleh pada saat pra siklus adalah hasil pengamatan yang dilihat pada saat didalam kelas. Data tersebut berbentuk lembar observasi yang diperoleh saat pengamatan kegiatan belajar sebelum dilakukan siklus I yang digambarkan dalam bentuk diagram.

Gambar 4.1

Grafik hasil kedisiplinan peserta didik pra siklus

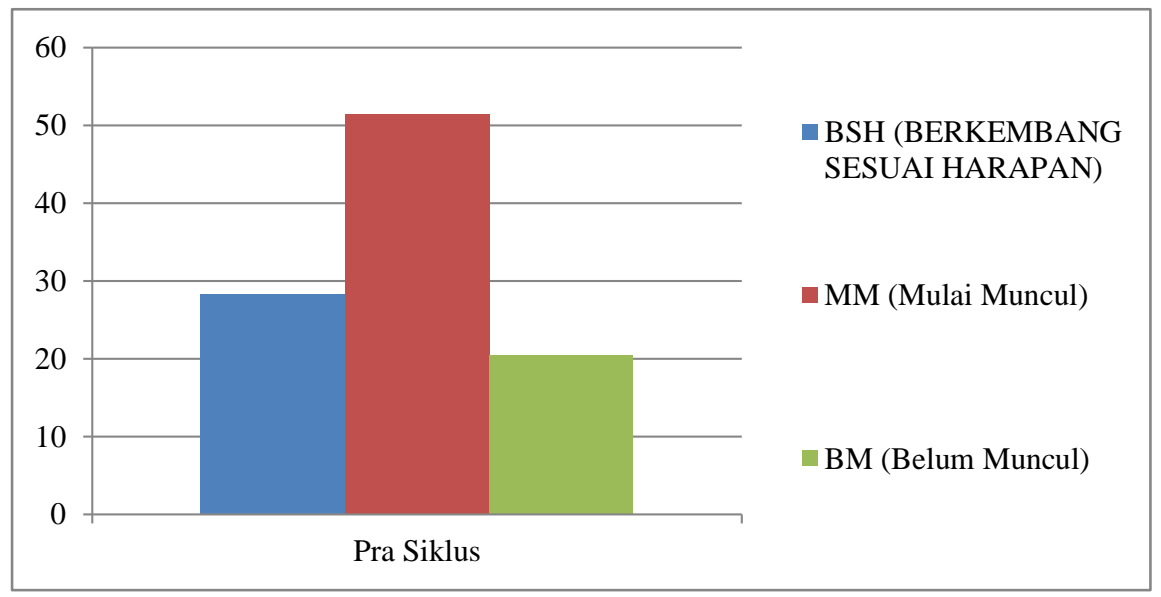

Berdasarkan hasil diagram diatas terlihat bahwa pada pra siklus ini tingkat disiplin peserta didik yang dilakukan di kelas A1 TK Islam Darunnajah 1 pada 6 butir penilaian sebelum dilakukan tindakan. Anak yang menunjukkan kedisiplinan berkembang sesuai harapan $28,2 \%$, anak yang kedisiplinannya mulai muncul 51,3\%, dan anak yang kedisiplinannya belum muncul sebesar $20,5 \%$.

2. Hasil Siklus I

1. Perencanaan

Siklus I ini dilakukan pada 9 Desember 2015. Pada tahap perencanaan ini ada beberapa hal yang dipersiapkan oleh peneliti, yaitu peneliti membuat Rencana Kegiatan Harian (RKH), menyiapkan lembar observasi, lembar evaluasi dan dokumentasi. Penelitian ini dilakukan pada jam 08.00 sampai dengan jam 09.15, pada siklus ini terdiri dari 2 hari pertemuan yaitu pada tanggal 9-10 Desember 2015. 
2. Pelaksanaan

1) Pertemuan 1

Pertemuan 1 dilaksanakan pada hari Rabu tanggal 9 Desember 2015.Kegiatan dimulai pada jam 08.00, guru mempersilahkan anak untuk minum sebelum memulai kegiatan dan guru memberikan perintah pada anak untuk duduk membentuk lingkaran dengan bernyanyi lagu "sit down, sit down, every body sit down on the floor, on the floor" maka anak-anak yang sudah minum dan berlarian segera duduk, karena posisi duduk berdesakan maka guru bernyanyi "lingkaran besar, lingkaran besar, lingkaran besar" namun masih ada 1 anak yang bermain boneka dan 1 anak yang tidur dilantai. Maka guru membuat gambar bunga matahari dipapan tulis dan menuliskan nama-nama anak yang telah duduk dengan tertib, kemudian anak 2 anak yang sedang bermain boneka dan tidur dilantai segera bergabung dilingkaran. Sebelum materi diberkan guru mengucapkan salam dan dengan kompak anak-anak menjawab salam, dilanjutkan dengan mengucapkan

"good morning student" dijawab anak "good morning teacher", "how are you today?" anak menjawab "fine thank you, and you?" guru menjawab "I am fine, thank you".

Setelah itu guru mulai bertanya "teman-teman, siapa yang tadi habis bangun tidur shalat subuh sama mama papa?", setengah dari anakanak dikelas mengangkat tangan, kemudian guru mengabsen dengan meminta anak berhitung secara bergiliran, setelah berhitung guru bertanya "teman-teman apakah ada teman kalian yang belum hadir?", ada anak yang menjawab "ada $r$ dan $t$, paling dia terlambat bu" kemudian guru menjelaskan "jam berapa kita harus sampai di TK?, ada anak yang menjawab jam tujuh, ada yang menjawab jam setengah delapan dan ada yang menjawab setengah tujuh. Kemudian guru menjelaskan "kita harus datang ke TK sebelum jam 7.30 atau sebelum ikrar dimulai ya", kemudian guru melanjutkan "teman-teman, bu guru lihat ada yang pakai baju belum rapi, coba dimasukan kedalam celana ya, bu guru bantu" maka ada dua anak yang bajunya belum rapi dibantu oleh guru.

Setelah itu guru membimbing anak untuk membaca surat $A l$ Lahab, anak-anak yang mengikuti membaca surat dengan semangat namanya ditulis dipapan tulis dan digambarkan bintang dengan spidol dilanjutkan dengan bernyanyi bersama lagu Fruits dengan tepuk tangan. Setelah bernyanyi guru bertanya kembali "siapa yang tahu apa saja sih peraturan kelas kita?" ada yang menjawab "jangan terlambat", "gak boleh lari-larian", "ga boleh males", "ga boleh teriak-teriak", guru menjawab "ya, semua benar" sambil menuliskan dipapan tulis "kalau kita lari-lari didalam kelas nanti bisakesandung temannya, kalau kita terik-teriak telinga jadi sakit dan bu guru ga bisa dengar apa yang kamu bicarakan, kalau kita males nanti kita jadi ga pintar, benar tidak?" anak-anak menjawab "benar!", pada saat percakapan berlangsung, satu anak pergi menjauh dan mengambil mainan masak-masakan, guru berkata "temanteman sekarang waktunya kita bermain atau belajar ya?" anak menjawab "belajar!", nah kalau waktunya belajar boleh tidak memegang maianan?" anak menjawab "gak boleh!", "nah, kalau begitu mainannya bisa disimpan 
dulu ya, kalau sudah selesai belajar kita bisa main bersama-sama", lalu satu anak itu ikut bergabung dalam lingkaran dengan membawa mainan ditangan, guru berkata kepada anak itu "e, mainannya mau kamu yang taruh di boks atau bu guru yang simpan?" akhirnya anak itu menyimpan mainan kedalam boks.

Kemudian guru melanjutkan kegiatan dengan menyiapkan anak "semuanya bersiap!" anak menjawab "siap!" dan seluruh anak telah duduk siap. Setelah anak-anak sudah dalam keadaan siap, kemudian guru mejelaskan tugas yang pertama sebelum itu guru membagikan satu kertas origami untuk tiap anak, setelah itu guru menjelaskan cara membuat origami bentuk bunga yang terdiri dari 3 lipatan, sambil guru mempraktekkan anak-anak diminta untuk mengikuti langkah-langkah yang dilakukan guru. Dalam proses pembuatan origami bunga, ada beberapa anak yang masih membutuhkan bantuan untuk membetuk segitiga, setelah selesai origami bunga tersebut ditempelkan pada buku gambar dan melengkapi gambar bunga dengan menambahkan batang daun dan rumput menggunakan krayon. Setelah selesai melipat origami dilanjutkan pada tugas ke dua yaitu mewarnai gambar menggunakan krayon sesuai perintah pada buku English. guru mengingatkan anak itu utuk segera menyelesaikan tugasnya karena sebentar lagi bu guru sentra akan datang. Setelah mengerjakan dua tugas yang diberikan, guru menambahkan gambar bintang dipapan tulis untuk anak yang tugastugasnnya telah selesai, anak-anak sangat senang karena bintangnya jadi tambah banyak. Kemudian bel sentra berbunyi pada jam 09.15, namun masih ada dua anak yang belum menyelesaikan tugasnya karena ikut bermain lego dengan temannya yang sudah selesai, akhirnya anak itu mau menyelesaikan tugasnya setelah diberikan sedikit bantuan dalam mewarnai gambar sesuai perintah.

Setelah jam sentra dan waktu istirahat jam 10.45, guru masuk kedalam kelas dan membimbing anak untuk merapikan mainan dengan bernyanyi "now it's time to tidy up, tidy up, tidy up, now it's time to tidy up", sambil bernyanyi anak-anak merapikan mainan, namun ada 1 anak yang masih bermain jadi guru mengingatkan dengan lembut tapi anak itu masih bermain, maka dengan suara yang tegas guru mengingatkan kembali dan berkata akan memberikan stiker bintang jika ia mau merapikan mainan pada tempatnya, akhirnya anak itu mau diminta merpikan mainan dan duduk bergabung dengan teman-teman.

2) Pertemuan 2

Pertemuan 2 dilaksanakan pada hari Kamis, 10 Desember 2015 pelaksanaan dimulai pada pukul 08.00-09.15, usai ikrar anak-anak dipersilahkan minum sebelum memulai kegiatan dan guru memberikan perintah pada anak untuk berdiri membentuk lingkaran dan diminta untuk mengikuti gerak senam sederhana, namun $i$ mengajak $h$ untuk main boneka, maka guru memanggil nama anak tersebut dan mengajak anak untuk bergabung dan mengingatkan jika anak-anak dapat belajar dengan tertib maka guru akan memberikan stiker bintang kemudian guru berkata "teman-teman coba lihat I dan h sudah bergabung dan duduk tertib kita beri tepuk tangan". Setelah itu guru dan anak duduk membentuk lingkaran, guru memberi salam dan anak-anak menjawabnya, dilanjutkan 
dengan mengucapkan "good morning student" dijawab anak "good morning teacher", "how are you today?" anak menjawab "fine thank you, and you?" guru menjawab "I am fine, thank you". Kemudian guru mengabsen dengan cara menulis nama dipapan tulis, dan menanyakan "apakah ada temannya yang belum datang?", z menjawab "r dan t", guru bertanya "teman-teman harus datang ke TK sebelum waktu ikrar yaitu jam tujuh lewat tigapuluh menit. Alhamdulillah kalian sudah datang tepat waktu tepuk tangan untuk kelas A1" anak-anak bertepuk tengan, "siapa yang shalat subuh berjamaah sama mama papa?" empat anak mengangkat tangan, "ayo kita bernyanyi bersama, bangun tidur ku terus mandi tidak lupa menggosok gigi habis mandi ku tolong ibu membersihkan tempat tidurku" dilanjutkan dengan tepuk semangat "Allahu Akbar prok prok prok, Allahu Akbar prok prok prok, Allahu Akbar prok prok prok yes!" dengan semangat anak mengikuti tepuk. Kemudian dilanjutkan dengan membaca surat Al Lahab diulang sebanyak dua kali secara klasikal, lalu guru meminta tiga anak untuk maju bergantian dan membacakan surat $\mathrm{Al}$ Lahab, saat membaca surat ada anak yang bermain lego, guru langsung memanggil anak tersebut dan mengingatkan peraturan dengan menyebutkan "bu Ishma senang dengan anak yang tertib ya, kalau kamu bisa tertib sampai selesai membaca surat, ibu akan kasih stiker bintang.", akhirnya anak itu segera menyimpan lego kedalam boks dan bergabung dengan teman lainnya. Sebelum masuk pada pemberian tugas bersamasama membaca basmallah, tugas pertama yaitu meniru huruf g, guru memberikan contoh cara membuat huruf g dipapan tulis dan meminta anak untuk maju sat-persatu menulis dipapan tulis, kemudian menyebutkan kata yang huruf dapannya dari g, dengan semangat anak-anak menyebutkan kata dari huruf g, ada anak yang belum tepat dan ada yang diam saja. Tugas kedua yaitu mencari 5 perbedaan pada dua gambar, masih ada anak yang kesulitan menemukan gambar yang berbeda.

Jam sudah menunjukkan pukul 09.00, guru memastikan anak-anak mengerjakan tugas sampai selesai, karena akan masuk ke jam sentra. Anak yang sudah menyelesaikan tugas diperbolehkan untuk bermain, bel berbunyi pukul 09.15 tandanya pergantian jam sentra, guru membimbing anak untuk merapikan mainan dan menyimpan pada tempatnya dengan bernyanyi "dirapikan, dirapikan mainanmu, mainanmu, ayo dirapikan, ayo dirapikan bersama, bersama-sama", sambil bernyanyi anak-anak merapikan mainan, namun ada anak yang tidak mau menyimpan mainan dan masih bermain, maka guru mengingatkan kembali akan memberikan stiker bintang jika mau merapikan mainan setelah digunakan.

\section{Observasi}

Setelah pelaksanaan, peneliti dan kolaborator mendiskusikan mengenai kegiatan yang telah dilaksanakan. Berdasarkan hasil pengamatan diperoleh data yaitu adanya beberapa peserta didik yang tidak aktif dalam proses belajar mengajar, ada beberapa anak yang belum mengetahui dan memahami tata tertib di sekolah, guru memberikan materi tata tertib kelas terlalu banyak, media pembelajaran disiplin yang peneliti sediakan kurang menarik bagi peserta didik, guru hanya sedikit memberikan pujian pada anak yang telah tertib. 
Gambar 4.2

Grafik tingkat kedisiplinan peserta didik pada siklus I

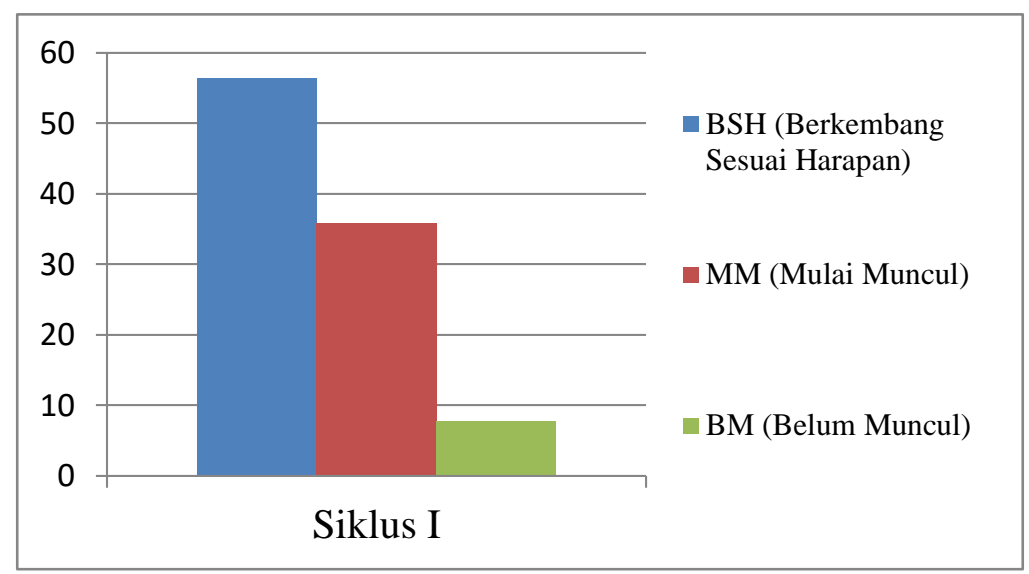

Berdasarkan hasil diagram diatas peningkatan disiplin anak usia 45 tahun pada Siklus I yang telah dilakukan di kelas A1 TK Islam Darunnajah1 menunjukkan kedisiplinan berkembang sesuai harapan 56,4 $\%$, anak yang kedisiplinannya mulai muncul 35,9 \%, dan anak yang kedisiplinannya belum muncul sebesar $7,7 \%$. Ini artinya dalam meningkatkan kedisiplinan peserta didik masih terlihat beberapa anak yang belum memahami dan mentaati tata tertib kelas. Disebabkan diterapkannya metode baru peningkatan disiplin oleh guru dan karena anak masih menyesuaikan diri dengan mematuhi tata tertib kelas yang disusun bersama.

\section{Refleksi}

Berdasarkan hasil observasi diketahui bahwa terdapat beberapa hal yang perlu diperbaiki, yaitu :

1) Saat guru mulai memasuki materi kondisi peserta didik belum siap seluruhnya karena masih ada yang memegang mainan dan ada yang tiduran dilantai. Jadi, guru perlu menyiapkan anak dengan menambahkan tepuk dan lagu agar anak dapat fokus dan siap untuk menerima materi.

2) Guru perlu lebih cekatan dengan cara memberikan perhatian lebih pada anak yang belum dapat mengerjakan tugas secara mandiri.

3) Guru perlu menggunakan buku cerita sebagai contoh perbuatan tentang kedisiplinan.

4) Peneliti harus mempersiapkan RKH dan perangkat pembelajaran dengan matang dan sesuai dengan perkembangan peserta didik.

Hasil refleksi kemudian dijadikan sebagai rumusan untuk diterapkan pada siklus II sebagai upaya tindak perbaikan terhadap peningkatan disiplin peserta didik pada siklus I.

3. Hasil Siklus II

a. Perencanaan

Pada tahap perencanaan ini ada beberapa hal yang dipersiapkan oleh peneliti, yaitu peneliti membuat Rencana Kegiatan Harian (RKH), menyiapkan alat/ media pembelajaran berupa buku cerita Islami, guru membuat papan reward dan stiker bintang, menyiapkan lembar observasi 
dan lembar evaluasi. Penelitian ini dilakukan pada jam 08.00 sampai dengan jam 09.15, pada siklus II terdiri dari tiga pertemuan yaitu pada tanggal 11, 14, 15 Desember 2015.

b. Pelaksanaan

1) Pertemuan 1

Pelaksanaan yang dilakukan dalam peningkatan disiplin pada anak di siklus II ini dimulai pada jam 08.00, guru mempersilahkan anak untuk minum sebelum memulai kegiatan dan guru memberikan perintah pada anak untuk berpegangan tangan membentuk lingkaran dengan bernyanyi lagu bernyanyi "lingkaran besar, lingkaran besar, lingkaran besar. Pak Tani punya kandang, besar, besar, besar didalamnya ada sapi moo, moo, moo, disini moo, disana moo, semua moo moo moo" kemudian berkata "sit down, sit down, every body sit down on the floor, on the floor" maka anak-anak yang sudah minum dan berlarian segera duduk, namun ada anak yang masih main berdua dibelakang.

Kemudian guru melanjutkan dengan mengucapkan salam dengan semangat dan dijawab dengan semangat juga, lalu guru menempelkan papan reward dan menjelaskan bahwa yang sudah datang tepat waktu, tertib, tugasnya selesai, pakai baju seragam dengan rapi dan bertanggung jawab dengan mainannya maka akan mendapatkan stiker bintang. Karena mendengar bu guru akan memberikan stiker bintang, kedua anak segera lari dan duduk bergabung dengan teman-temannya. Bu guru memberikan pujian untuk semua anak karena sudah duduk tertib dan dianggap telah dapat menerima materi,.

Guru telah menyiapkan display asturo dipapan tulis untuk menuliskan tata tertib kelas, dimulai dengan perntanyaan "teman-teman apa saja peraturan dikelas?", anak-anak menjawab "ga boleh lari-larian, ga boleh terlambat, ga boleh bercanda, yang anak perempuan pakai kerudung yang anak laki-laki pakai peci, ga boleh males" a, e, g, g, r, s, s, z, t, z dengan semangat dapat menyebutkan lebih dari 3 peraturan kelas, sedangkan a, i hanya menyebutkan 1 peraturan kelas. Maka guru menuliskan satu persatu pada display tata tertib kelas yang telah disiapkan. Setelah itu guru mulai mengawali kegiatan dengan membaca basmallah dan bernyanyi lagu kebunku dengan membuat gerakan sederhana, saat bernyanyi semua anak ikut aktif bernyanyi.

Dilanjutkan degan tepuk wudhu, membaca niat wudhu dan doa masuk kamar mandi, dan anak-anak berbaris keluar menuju kamar mandi untuk berwudhu, saat tiba dikamar mandi ada anak yang menyelak antrian temannya, segera guru ingatkan untuk berdiri sesuai dengan barisan tadi dan bersabar menunggu gilirannya, akhirnya anak itu mau antri. Selesai wudhu guru merapikan shaf shalat dan anak memakai mukena sendiri. Guru memimpin praktek shalat subuh, dan ada 2 anak yang belum mengikuti shalat dengan tertib, selesai salam guru memandu anak untuk membaca istighfar dan tasbih dilanjutkan dengan berdoa dan diakhiri dengan bersalam-salaman. Kegiatan praktek shalat berjalan cukup tertib dan guru memberikan pujian dan satu stiker bintang bagi anak-anak yang telah tertib dan mengingatkan pada 2 anak yang belum tertib apa yang tadi dilakukan ketika shalat maka dia tidak dapat stiker bintang. 
Selesai praktek shalat, guru menyiapkan anak dengan tepuk anak sholeh dan duduk membentuk lingkaran, dilanjutkan dengan membacakan buku cerita Islami. Saat guru membacakan cerita anak-anak mendengarkan dan tertib, hanya aja ada anak yang member komentar. Selesai baca cerita kemudian tanya jawab tentang isi cerita, ada anak yang bisa dan tidak bisa namun dapat terlihat perubahan ketika ada temannya yang tidak mau mengerjakan tugas anak lain dapat menasehati atau mengingatkan.

\section{2) Pertemuan 2}

Pertemuan dua dilaksanalan pada hari Senin, 14 Desember 2015 dengan durasi 60 menit. Kegiatan diawali pada jam 08.00, setelah ikrar anak dipersilahkan untuk minum sambil duduk, setelah minum guru memberikan instruksi pada anak untuk membentuk barisan dan melakukan gerak sesuai dengan lirik lagu "walking, walking, walking, walking, jump, jump, jump, running, running, running, now let's stop, now let's stop, berjalanlah, berjalanlah, melompat, melompat, lari-lari, lari-lari, lari-lari, berhenti, berhenti lagi", dengan antusias seluruh anak mengikuti gerakan, dilanjutkan dengan tepuk "sit down, sit down, every body sit down on the floor, on the floor" maka ada anak yang sedang mengobrol segera menuju karpet dan duduk membentuk barisan 2 shaf. Kemudian guru mengucapkan salam dengan semangat dan dijawab pula dengan semangat oleh anak, dilanjutkan dengan mengucapkan "good morning student" dijawab anak "good morning teacher", "how are you today?" anak menjawab "fine thank you, and you?" guru menjawab "I am fine, thank you" dilanjutkan dengan tepuk pagi dan tepuk semangat. Setelah itu guru mengabsen dengan cara berhitung secara berurutan dari kanan ke kiri, dan menanyakan siapa yang belum hadir, ada yang menjawab bahwa ada satu temannya yang belum hadir karena sakit, lalu guru memberikan pujian pada anak yang sudah datang ke TK "alhamdulillah, terimakasih untuk anak A1 yang datangnya tidak terlambat" anak-anak tersenyum ketika diberi pujian, lalu guru memberikan stiker bintang. Sebelum memasuki tugas pertama guru menjelaskan kembali peraturan kelas dengan membacakan dengan kalimat sederhana diplay tulisan tata tertib kelas yang telah dipasang dipapan tulis, anak-anak menyimak guru sambil melihat display tata tertib kelas, lalu ada anak yang komentar "tadi si fulan lari-lariaan bu, nantikan bisa kepeleset ya bu" guru menjawab "iya benar, jadi boleh tidak kita berlarian didalam kelas?" anak-anak menjawab "tidak boleh", dilanjutkan dengan membaca do'a berpakaian, anak yang mengikuti do'a diberikan stiker bintang dan menempelkan pada nama masing-masing.

Kemudian masuk kepada materi, guru membacakan buku cerita tanaman yang menjelaskan tentang bagian tanaman dan cara merawatnya, anak-anak mendengarkan cerita dengan tenang. Usai membaca buku cerita guru menjelaskan materi dengan membawa tanaman hias kedalam kelas dengan menunjukkan bagian-bagian tanaman, saat menjelaskan anak-anak dengan antusias menyimak guru. Setelah menjelaskan guru bertanya tentang nama-nama bagian tanaman sambil memegang bagian tanaman, rata-rata anak dapat menjawab dengan benar. setelah masuk ke materi berikutnya yaitu hafalan do'a berpakaian, dengan cara dibaca bersama lalu 
maju tiga orang secara bergantian, bagi anak yang membaca dengan semangat guru memberikan stiker bintang, anak-anak sangat senang dan antusias sehingga materi dapat dikuasi oleh anak. Setelah belajar anak diperbolehkan untuk bermain lego bersama sampai jam 09.10, lalu guru member perintah untuk merapikan mainan dengan bernyanyi "dirapikan, dirapikan, mainanmu, mainanmu, ayo dirapikan, ayo dirapikan, bersama, bersama-sama", sambil bernyanyi pula anak-anak merpikan mainan. Jam 09.15 bel sentra berbunyi dan guru sentra masuk ke dalam kelas.

\section{3) Pertemuan 3}

Pertemuan ini dilaksanakan pada hari Selasa, 15 Desember 2015. Pelaksanaan dilakukan pada jam 08.00 setelah ikrar bersama, anak masuk kedalam kelas masing-masing. Guru menyiapkan anak untuk membentuk lingkaran besar dan bernyanyi "If you happy and you know it clap your hand $2 x$, if you happy and you know it and you really want to show it, if you happy and you know it clap your hand..." dengan semangat anak bertepuk tangan, namun ada satu anak yang diam maka guru berkata keseluruh anak "are you ready!" anak-anak menjawab "yes, ready!". Kemudian guru meminta anak berhitung dengan Bahasa Inggris satu persatu lalu duduk, kemudian guru bertanya "how many student in the class?" ada satu anak yang bisa menjawab "thirteen", guru berkata "yes, good job $z "$.

Sebelum memulai kegiatan bersama-sama mengucapkan basmallah dan mengulangi hafalan do'a berpakaian secara klasikal diulangi sebanyak tiga kali. Anak yang mengikuti hafalan do'a berpakaian diberikan stiker bintang oleh guru dan menmpelkannya pada nama masing-maing anak, namun ada dua anak yang tidak dapat bintang karena tidak ikut bersamasama membaca hafalan do'a, anak itu cemberut dan memaksa guru untuk memberikan bintang, akhirnya guru memberikan kesempatan bagi untuk membacakan do'a berpakaian, sehingga dia mendapatkan stiker dari guru, sebelum diberikan guru berkata "Nah kalau gitu kamu harus ikut membaca do'a bersama teman-teman bukannya malah bermain", anak itu mengangguk. Masuk pada pemberian tugas mengerjakan buku Pandai Bahasa dan Math, guru menjelaskan dengan menuliskan serta menggambarkan kembali di papan tulis dan member kesempatan anak yang masih belum paham maju kedepan untuk mengerjakan contoh dipapan tulis. Pada jam 09.00 guru memastikan anak-anak telah menyelesaikan tugas masing-masing, namun masih ada satu anak yang belum selesai dan butuh bimbingan dari guru. Usai belajar guru menginstruksikan untuk duduk melingkar dikarpet dan memberikan stiker bintang untuk anak yang telah mengerjakan tugas yang diberikan, anak dipanggil satu persatu dan diberikan stiker kemudian menempelkannya pada namanya masing-masing. Pukul 09.15 guru sentra datang masuk kedalam kelas.

c. Observasi

Peneliti dan kolaborator mendiskusikan mengenai kegiatan yang telah dilaksanakan dan memperoleh data anak yang tingkat disiplinnya rendah mempunyai gaya belajar audio dan visual sehingga peneliti perlu memberikan materi dengan suasana yang menyenangkan dengan bernyanyi dan intonasi suara guru yang tegas. Berdasarkan hasil 
pengamatan yang diperoleh secara keseluruhan peserta didik mengetahui dan dapat menjalankan tata tertib di sekolah.

Gambar 4.3

Grafik tingkat kedisiplinan peserta didik pada siklus II

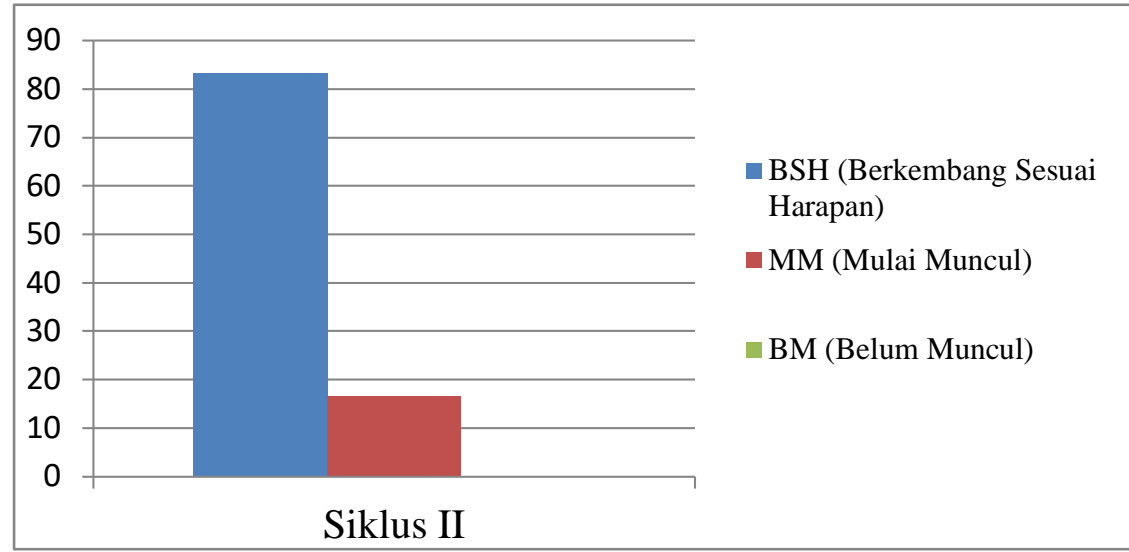

Berdasarkan hasil diagram peningkatan disiplin anak usia 4-5 tahun pada Siklus II yang telah dilakukan di kelas A1 TK Islam Darunnajah 1 menunjukkan kedisiplinan berkembang sesuai harapan 83,3 $\%$, anak yang kedisiplinannya mulai muncul $16,7 \%$, dan anak yang kedisiplinannya belum muncul $0 \%$. Ini artinya, seluruh peserta didik sudah melakukan kegiatan dengan tertib namun masih ada anak yang perlu diingatkan berulang kali oleh guru.

d. Refleksi

Berdasarkan hasil observasi, anak sudah dapat mengetahui peraturan kelas dan mulai menjalaninya tanpa perlu diingatkan berulang kali. Dan diketahui bahwa terdapat beberapa hal yang perlu diperbaiki, yaitu :

1) Dalam memberikan materi guru perlu mengkondisikan suasana yang menyenangkan dengan bernyanyi dan intonasi suara yang tegas.

2) Guru perlu memfokuskan dan mengatakan berulangkali untuk mengingatkan peraturan kelas yang disepakati bersama anak sebelum proses belajar mengajar berlangsung atau pada saat ikrar.

3) Guru perlu memberikan motivasi lebih kepada anak yang disiplinnnya rendah dengan memberikan pujian meskipun perubahan disiplin pada anak tersebut hanya sedikit.

Hasil refleksi kemudian dijadikan sebagai rumusan untuk diterapkan pada siklus III sebagai upaya tindak perbaikan terhadap peningkatan disiplin peserta didik pada siklus II.

4. Hasil Siklus III

a. Perencanaan

Pada tahap perencanaan ini ada beberapa hal yang dipersiapkan oleh peneliti, yaitu peneliti membuat Rencana Kegiatan Harian ( RKH ), menyiapkan alat/ media pembelajaran, guru menyiapkan tepuk dan lagu dengan gerak sederhana, memasang display tata tertib kelas, guru membuat stiker bintang menyiapkan lembar observasi, lembar evaluasi dan pendokumentasian. Pada siklus III penelitian dilakukan pada tanggal 18 dan 21 Desember 2015. 
b. Pelaksanaan

1) Pertemuan 1

Pertemuan 1 dilakukan pada hari Jum'at, 18 Desember 2015. Pelaksanaan dimulai pada jam 08.00 sampai dengan jam 09.00, guru mempersilahkan anak untuk minum sebelum memulai kegiatan dan guru memberikan perintah pada anak untuk berpegangan tangan membentuk lingkaran dan berhitung menggunakan Bahasa Inggris satu persatu kemudian duduk, setelah itu guru mengucapkan salam dengan semangat dan dijawab pula dengan semangat dan guru mengabsen anak yang sudah hadir, seluruh anak sudah hadir dan tidak ada yang terlambat, maka guru memberikan pujian "Alhamdulillah anak A1 tidak ada yang datang terlambat, tepuk tangan untuk kita semua" lalu guru memberikan stiker bintang kepada masing-masing anak untuk ditempel di papan reward dan dilanjutkan dengan tepuk pagi, tepuk anak shaleh, tepuk semangat dan bernyanyi bersama lagu menanam jagung.

Kemudian guru menjelaskan dengan semangat kegiatan hari ini yaitu bermain peran sebagai koki, anak anak diperkenalkan dengan sayur kacang panjang dan terong yang telah disiapkan guru, kemudian memotong motong sayur dengan pisau plastik dan memasaknya, anakanak sangat senang dan mengikuti kegiatan dengan baik. Setelah selesai bermain peran sebagai koki, guru memberikan arahan untuk membuang sampah ke tempat sampah dan mencuci alat masak masakan yang sudah digunakan. Kegiatan dilanjutkan dengan praktek shalat diawali dengan tepuk wudhu, niat wudhu dan doa masuk kamar mandi. Dengan tertib anak-anak berbaris menuju kamar mandi dan sabar menunggu giliran untuk wudhu. Kegiatan praktek shalat dipimpin oleh bu guru, sebelum shalat dimulai guru mengingatkan tata cara shalat, yaitu pandangan kesajadah, tidak boleh bercanda, harus mengikuti gerakan imam dan tertib, bagi anak yang tertib guru akan memberikan pujian dan stiker bintang. Maka semua anak dapat mengukuti praktek shalat dengan baik tidak ada yang bercanda, namun ada beberapa anak yang gerakkan shalatnya masih butuh bimbingan. Setelah praktik shalat guru melakukan evaluasi dengan menanyakan "Apakah ada yang shalatnya bercanda dan ngobrol sama teman?" anak menjawab sambil menggelengkan kepala "tidak bu..", tadi bu guru lihat ada loh yang masih ngobrol sama temannya, boleh tidak?" anak menjawab "tidak boleh bu", kemudian guru memberikan pujian "Alhamdulillah anak A1 shalatnya tertib shalatnya khusuk" sambil diberikan dua jari jempol.

2) Pertemuan 2

Pertemuan dua dilaksanakan pada hari Senin, 21 Desember 2015. Kegiatan dimulai pada pukul 08.00 sampai dengan 09.15, setelah ikrar anak dipersilahkan untuk minum sambil duduk, setelah minum guru memberikan instruksi pada anak untuk membuat lingkaran besar dan melakukan tepuk konsentrasi, tepuk pagi, tepuk semangat dan tepuk rukun Islam,dengan melakukan tepuk anak menjadi fokus dan menyimak yang guru ucapkan, guru memberi salam dengan semangat dan dijawab dengan semangat oleh anak.

Kemudian guru menirukan menjadi pohon dengan seluruh anggota badan, anak-anak meniru dengan antusias mengikuti gerakan proses pohon 
yang tumbuh dari biji sehingga menjadi pohon yang besar lalu tertiup angin, dilanjutkan dengan gerak dan lagu menanam jagung, anak-anak sangat senang dalam menirukan gerakan. Kegiatan dilanjutkan dengan tepuk "sit down, sit down, every body sit down on the floor, on the floor" seluruh anak duduk membentuk dua shaf, kemudian guru mengabsen anak dengan menuliskan nama dipapan tulis dan berkata "teman-teman hari ini bu guru senang sekali loh, karena semua anak A1 tidak ada yang terlambat datang ke TK" anak-anak tersenyum. Kemudian kegiatan dilanjutkan dengan hafalan do'a naik kendaraan dengan display tulisan dan diulangi 3 kali secara bersama dan untuk mengulangi hafalan do'a naik kendaraan dengan membagi menjadi dua kelompok agar anak lebih termotivasi. Guru memerikan motivasi bagi anak yang belum hafal dengan mengatakan "Ayo semangat suaranya dikeluarkan" anak itu pun mengikuti dengan suara yang lebih kencang.

Dilanjutkan dengan membaca Asma'ul Husna bersama-sama sebelum masuk pada penjelasan materi. Kemudian guru menjelaskan tugas-tugas yang akan dikerjakan dengan menggunakan media bendabenda didalam kelas pada materi buku English dan mewarnai gambar buah-buahan sesuai dengan perintah. Kemudian guru memastikan anakanak telah menyelsaikan tugas, namun masih ada anak yang perlu bimbingan guru. Setelah selesai guru memperbolehkan anak untuk bermain dan sebelumnya mengingatkan jika jarum panjang diangka 2 , maka waktu bermain selesai dan harus merapikan mainan pada tempatnya sebelum guru sentra datang, dan anak-anak dengan semangat merapikan mainan pada tempatnya bahkan saling membantu temannya.

c. Observasi

Setelah pelaksanaan, peneliti dan kolaborator mendiskusikan mengenai kegiatan yang telah dilaksanakan. Berdasarkan hasil pengamatan maka diperoleh data belum secara keseluruhan anak mengetahui tata tertib di sekolah, anak dapat merapikan maianan segera setelah digunakan tanpa diingatkan oleh guru, anak yang biasanya datang setelah selesai ikrar menjadi datang sebelum ikrar karena ditanyakan oleh temannya jika datang terlambat, anak berpakaian seragam lengkap dan rapi namun masih ada 2 anak yang tidak menggunakan kerudung pada hari Jum'at, anak sudah dapat mengingatkan jika ada temannya yang belum tertib dan berlomba lomba untuk mendapatkan reward yang diberikan guru.

Gambar 4.4

Grafik tingkat kedisiplinan peserta didik pada siklus III

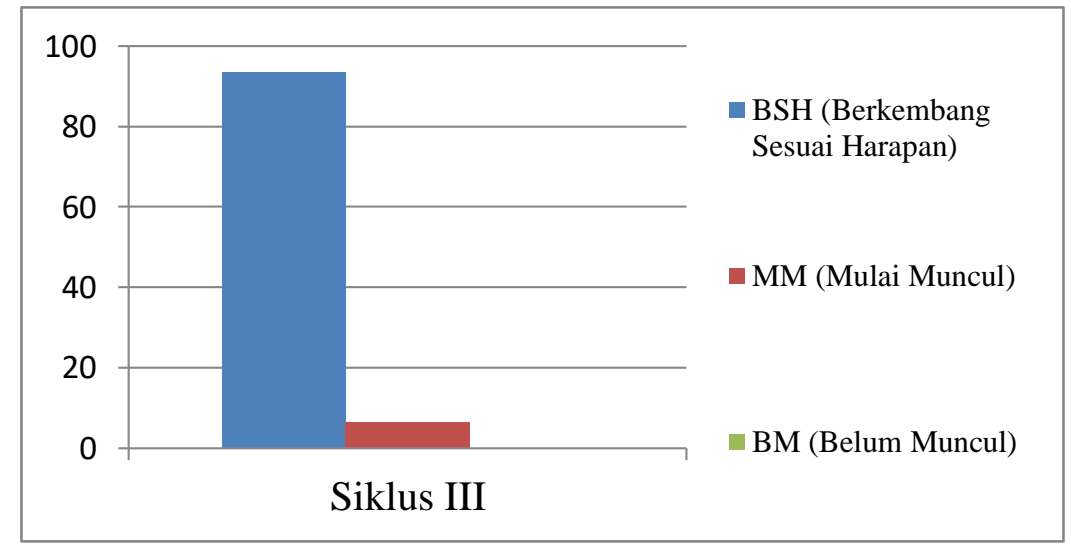


Berdasarkan gambar hasil diagram peningkatan disiplin anak usia 4-5 tahun pada Siklus III yang telah dilakukan di kelas A1 TK Islam Darunnajah 1 menunjukkan kedisiplinan berkembang sesuai harapan sebesar 93,6 \%, anak yang kedisiplinannya mulai muncul sebesar 6,4 \%, dan anak yang kedisiplinannya belum muncul $0 \%$. Hal ini menunjukkan bahwa penerapan disiplin yang digunakan peneliti dapat meningkatkan disiplin anak usia 4-5 tahun telah berhasil dan mencapai target $90 \%$. Metode ini efekif digunakan dalam melaksanakan proses kegiatan belajar mengajar selanjutnya.

Dari data hasil observasi digunakan untuk mengetahui tingkat kedisiplinan peserta didik dalam proses belajar mengajar, anak dapat menunjukkan sikap disiplin dikelas dan dapat mengingatkan temannya jika ada yang melanggar peraturan.

d. Refleksi

Berdasarkan hasil observasi diperoleh peningkatan kedisiplinan pesera didik pada anak usia 4-5 tahun berkembang sesuai harapan sebesar 93,6 \%. Guru telah berhasil menciptakan suasana pembelajaran menjadi lebih efektif dengan meningkatnya kedisiplinan peserta didik dan peserta didik menjadi lebih baik dalam mengkontrol diri dan semakin termotivasi untuk dapat melakukan kegiatan pembelajaran dengan tertib. Dalam pelaksanaan pembelajaran, guru telah berusaha secara kontinyu dan konsisten penerapkan metode pembiasaan dan menciptakan semangat disiplin pada anak.

\section{Pembahasan}

1. Siklus I

Selama proses belajar mengajar berlangsung, peserta didik melakukan kegiatan-kegiatan yang telah dirancang oleh peneliti didalam Rencana Kegiatan Harian. Selama pelaksanaan siklus I, diperoleh data bahwa masih ada beberapa anak yang belum mengetahui apa saja peraturan di sekolah dan media pembelajaran disiplin yang peneliti sediakan kurang menarik perhatian peserta didik.

Hasil dari siklus I menunjukkan yang berkembang sesuai harapan sebesar 56,4\%, anak yang kedisiplinannya mulai muncul 35,9\%, dan anak yang kedisiplinannya belum muncul sebesar 7,7 \%. Persentasi ini menggambarkan bahwa siklus I belum mencapai target yang diharapkan. Hal ini diakibatkan karena :

a. Ada beberapa peserta didik yang tidak aktif dalam proses belajar mengajar.

b. Ada beberapa anak yang belum mengetahui dan memahami tata tertib di sekolah.

c. Dalam menjelaskan terlalu banyak materi yang diberikan.

2. Siklus II

Dalam pelaksanaan siklus II, peneliti mempersiapkan Rencana Kegiatan Harian. Peneliti memperbaiki caramengajarnya agar peserta didik termotivasi untuk mentaati tata tertib di sekolah dan membuat suasana pembelajaran semakin menarik dan menyenangkan yaitu dengan membuat papan reward yang ditambah dengan stiker bintang jika anak tertib. Dengan demikian, peneliti memacu peserta didik untuk dapat 
memberikan contoh yang baik dan dapat mengingatkan anak yang melanggar peraturan. Tindakan yang dilakukan dalam siklus II adalah :

a. Guru menjelaskan kedisiplinan dengan memberikan contoh nyata dengan melakukan evaluasi pada tiap anak setelah kegiatan berlangsung

b. Guru memberikan motivasi agar peserta didik mampu berlomba dalam berdisiplin

c. Guru menciptakan media yang menarik dan menyenangkan melalui pemberian reward.

Langkah-langkah perbaikan tindakan yang dilakukan pada siklus II memberikan dampak positif pada peningkatan disiplin anak usia 4-5 tahun di Sekolah. Hasil peningkatan peserta didik pada siklus II yaitu yang berkembang sesuai harapan 3,3\%, anak yang kedisiplinannya mulai muncul 16,7 \%, dan anak yang kedisiplinannya belum muncul $0 \%$. Dengan demikian, pada siklus II ini terjadi peningkatan disiplin anak di sekolah, akan tetapi belum mencapai keberhasilan yang diharapkan. Oleh karena itu guru menyusun kembali upaya perbaikan pada siklus III.

3. Siklus III

Dalam pelaksanaan siklus III, peneliti mempersiapkan Rencana Kegiatan Harian. guru semakin memperbaiki cara mengajarnya agar dapat lebih menarik peserta didik dan termotivasi lagi untuk dapat lebih mentaati tata tertib kelas. Guru lebih membimbing dalam memberikan teladan yang baik supaya dapat ditiru oleh peserta didik. Tindakan yang dilakukan dalam siklus III adalah :

a. Guru menjelaskan kedisiplinan dengan memberikan contoh nyata dengan melakukan evaluasi pada tiap anak setelah kegiatan berlangsung.

b. Guru memberikan motivasi agar peserta didik mampu berlomba dalam berdisiplin.

c. Guru memberikan reward kepada peserta didik yang tertib mengikuti proses belajar mengajar berupa pujian dan stiker bintang.

Berikut ini adalah rekapitulasi data pada penetilitan tindakan kelas dari siklus I, II dan III dalam bentuk tabel dan grafik.

Tabel 4.1

Rekapitulasi hasil peningkatan disiplin usia 4-5 tahun

\begin{tabular}{|c|c|c|c|c|}
\hline Kriteria & $\begin{array}{c}\text { Pra } \\
\text { Siklus }\end{array}$ & Siklus I & Siklus II & $\begin{array}{c}\text { Siklus } \\
\text { III }\end{array}$ \\
\hline BSH & $28,2 \%$ & $56,4 \%$ & $83,3 \%$ & $93,6 \%$ \\
\hline MM & $51,3 \%$ & $35,9 \%$ & $16,7 \%$ & $6,4 \%$ \\
\hline BM & $20,5 \%$ & $7,7 \%$ & $0 \%$ & $0 \%$ \\
\hline
\end{tabular}


Gambar 4.5

Grafik hasil pra siklus, siklus I, siklus II, siklus III

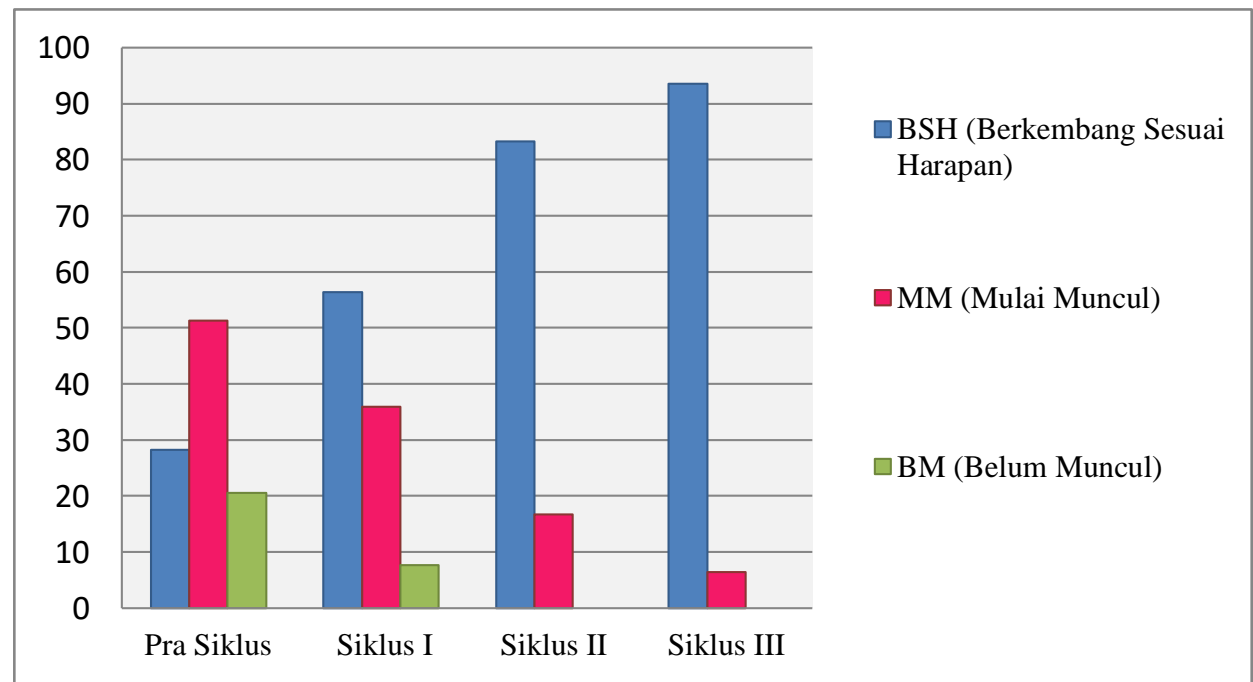

Berdasarkan hasil penelitian yang telah dikemukakan di atas, pada siklus I, siklus II dan siklus III terjadi peningkatan kedisiplinan anak usia 4-5 tahun yang menunjukkan adanya perubahan yang baik. Pada siklus I peserta didik yang berada dalam kategori berkembang sesuai harapan berjumlah 56,4\%. Setelah diadakan perbaikan pada siklus II, kedisiplinan peserta didik menjadi meningkat, peserta didik yang berkembang sesuai harapan menjadi 83,3\%. Kemudian dilakukan perbaikan kembali pada siklus III, kedisiplinan peserta didik hingga $93,6 \%$.

\section{KESIMPULAN}

Berdasarkan hasil penelitian maka dapat diambil kesimpulan yaitu melalui metode pembiasaan guru dapat meningkatkan disiplin anak usia 4-5 tahun yang ditandai dari hasil analisis data pada siklus I yang berada dalam kategori berkembang sesuai harapan berjumlah $56,4 \%$, lalu pada siklus II menjadi $83,3 \%$ dan pada siklus III mencapai 93,6\%. Penerapan metode pembiasaan dapat meningkatkan disiplin anak usia 4-5 tahun di TK Islam Darunnajah yang telah mencapai target $90 \%$.

Disiplin anak dapat ditingkatkan dengan metode pembiasaan dengan memberikan contoh teladan kepada peserta didik, memberikan motivasi, dalam menanamkan kedisiplinan dilakukan secara kontinyu dan konsisten. Selain itu juga diiringi dengan tepuk dan lagu, membacakan cerita-cerita Islami, disertai dengan pemberian reward berupa pujian dan stiker bintang. 


\section{DAFTAR PUSTAKA}

Aqib, Zainal., et al. 2009. Penelitian Tindakan Kelas Untuk Guru, SD, SLB, TK. Bandung : CV. Yrama Widya.

Dariza, Syafrina. 2011. Skripsi : Peran Guru Konseling Dalam Meningkatkan Disiplin Siswa di SMP Al-Ghozali Bogor. Jakarta: UIN Syarif Hidayatullah.

Departemen Pendidikan Nasional. 2007. Pedoman Pembelajaran Bidang Pengembangan Pembiasaan di Taman Kanak-kanak. Jakarta.

Desmita. 2005. Psikologi Perkembanga. Bandung : PT Kembang Rosdakarya.

Durkheim, Emil. 1990. Pendidikan Oral (Suatu Studi Teori dan Aplikasi Sosiologis Pendidikan). Jakarta : Erlangga.

Gunarsa, Singgih. 2012. Psikologi untuk Membimbing. Jakarta : Libri.

Gunawan, Ary H. Sosiologi Pendidikan. Jakarta : PT Rineka Cipta.

Hurlock, Elizabeth B. 1999. Perkembangan Anak Jilid 2. Jakarta : Erlangga.

Indrakusuma, Amir Daien. 1973. Pengantar Ilmu Pendidikan. Surabaya : Usaha Nasional.

Jamarah, Syaiful Bahri. 2000. Guru dan Anak Didik dalam Interaksi Edukatif. Jakarta : PT Rineka Cipta.

Kunandar. 2008. Langkah Mudah Penelitian Tindakan Kelas Sebagai Pengembangan Profesi Guru. Jakarta : PT Raja Grafindo Persada.

Mansur, Muslich. 2009. Melaksanakan PTK itu Mudah Classroom Action Research. Jakarta : PT Bumi Aksara.

Nizar, Imam Ahmad Ibnu. 2011. Membentuk dan Meningkatkan Disiplin Anak Sejak Dini. Jakarta : Diva Press.

Pemerintah R.I. 2006. Undang-Undang Republik Indonesia No. 14 Tahun 2003 Tentang Guru dan Dosen. Bandung : Citra Umbara.

Pemerintah R.I. 2010. Peraturan Menteri Pendidikan Nasional Republik Indonesia No. 58 Tahun 2009, Tentang Pendidikan Anak Usia Dini.

Pratisti, Dinar Wiwien. 2008. Psikologi Anak Usia Dini. Bogor : PT Indeks.

Pusat Bahasa. 2016. Kamus Besar Bahasa Indonesia Online. http://kbbi.web.id/metode diunduh 20 Juni 2016.

Rohani, Ahmad. 2004. Pengelolaan Pengajaran. Jakarta : Rineka Cipta.

Sabri, M. Alisuf. 2005. Pengantar Ilmu Pendidikan. Jakarta : UIN Jakarta Press.

Santrock, W. John. 2007. Perkembangan Anak Sejak dalam Kandungan. Jogjakarta : Diva Press.

Semiawan, Conny R. 2006. Penerapan Pembelajaran Pada Anak. Jakarta : PT Index.

Sutisna, Oteng. 1993. Administrasi Pendidikan (Dasar Teoritis untuk Praktek Professional). Bandung : Angkasa. 
Tu’u, Tulus. 2004. Peran Disiplin pada Perilaku dan Prestasi Siswa. Jakarta : PT Grasindo.

Wibowo, Agus. 2012. Pendidikan Karakter Usia Dini (Strategi Membangun Karakter di Usia Emas). Yogyakarta: Pustaka Pelajar.

Wijaya, Cece. 1994. Psikologi Bermasalah. Jakarta : Libri. 